\title{
Diploid hybrid fish derived from the cross between female Bleeker's yellow tail and male topmouth culter, two cyprinid fishes belonging to different subfamilies
}

Shengnan $\mathrm{Li}^{1,2+}$, Lihua Xie ${ }^{1,2+}$, Jun Xiao ${ }^{1,2}$, Liujiao Yuan ${ }^{1,2}$, Tian Zhou ${ }^{1,2}$, Kaikun Luo ${ }^{1,2}$, Chun Zhang ${ }^{1,2}$, Rurong Zhao ${ }^{1,2}$, Min Tao $^{1,2^{*}}$ and Shaojun Liu ${ }^{1,2^{*}}$

\begin{abstract}
Background: Bleeker's yellow tail (Xenocypris davidi Bleeker, YT) and topmouth culter (Culter alburnus Basilewsky, TC) are both famous and important economic freshwater fish in China. YT, a kind of omnivorous fish, has strong resistance. TC, a kind of carnivorous fish, has high-quality meat but poor resistance. Distant hybridization can integrate the advantages of both parents. There has been no previous report regarding hybrid fish derived from female $Y T \times$ male TC. It is expected that hybridization of these two kinds of fish will result in $F_{1}$ hybrids with improved characteristics, such as faster growth rate, stronger resistance, and high-quality meat, which are of great significance in fish genetic breeding.

Results: In this study, we investigated the main biological characteristics of diploid hybrid fish derived from female YT $\times$ male TC. The hybrids had an intermediate number of upper lateral line scales between those for YT and TC. The hybrids were diploids with 48 chromosomes and had the same karyotype formula as their parents. The hybrids generated variations in 5 S rDNA (designated class IV: $212 \mathrm{bp}$ ) and lost specific 5S rDNA derived from the maternal parent (designated class II: $221 \mathrm{bp}$ ), which might be related to hybridization. In terms of reproductive traits, all the tested female hybrids exhibited normal gonadal development, and the two-year-old $F_{1}$ females produced mature eggs. However, all the tested testes of the male hybrids could not produce mature sperm. It is possible that the hybrid lineage will be established by back-crossing the fertile female hybrids and their parents.
\end{abstract}

Conclusions: Obtaining a fertile female hybrid fish made the creation of a new type of fish possible, which was significant in fish genetic breeding.

Keywords: Biological characteristics, Diploid hybrid fish, Distant hybridization, Ovary development

\section{Background}

In fish, distant hybridization is the mating of two species of fishes that may involve crosses between different species or higher-ranking taxa [1,2]. Hybridization can combine parental advantages and result in offspring with traits superior to those of the parents, such as faster growth rate, stronger disease resistance, and higher survival rate. Hybridization is universally believed to play a

\footnotetext{
* Correspondence: minmindiu@126.com; Isj@hunnu.edu.cn

+Shengnan Li and Lihua Xie contributed equally to this work.

'State Key Laboratory of Developmental Biology of Freshwater Fish, Hunan

Normal University, Changsha 410081, Hunan, China

Full list of author information is available at the end of the article
}

significant role in the formation of polyploidy. For example, previous studies indicated that allotetraploid hybrid lineages $\left(\mathrm{F}_{3}-\mathrm{F}_{27}\right)$ were obtained from the hybridization of female red crucian carp (Carassius auratus red var., RCC) and male common carp (Cyprinus carpio L., CC) [1-3]. Autotetraploid fish lineages $\left(\mathrm{F}_{2}-\mathrm{F}_{13}\right)$ and homologous diploid strains of red crucian carp $\left(\mathrm{F}_{1}-\mathrm{F}_{13}\right)$ were derived from the hybridization of female RCC and male blunt snout bream (Megalobrama amblycephala, BSB) [2, 4]. Allodiploid fish lineages $\left(\mathrm{F}_{1}-\mathrm{F}_{5}\right)$ were produced from the hybridization of female BSB and male topmouth culter (Culter alburnus Basilewsky, TC) $[2,5,6]$. Allodiploid fish lineages $\left(F_{1}-F_{5}\right)$

(c) The Author(s). 2019 Open Access This article is distributed under the terms of the Creative Commons Attribution 4.0 International License (http://creativecommons.org/licenses/by/4.0/), which permits unrestricted use, distribution, and reproduction in any medium, provided you give appropriate credit to the original author(s) and the source, provide a link to the Creative Commons license, and indicate if changes were made. The Creative Commons Public Domain Dedication waiver (http://creativecommons.org/publicdomain/zero/1.0/) applies to the data made available in this article, unless otherwise stated. 
were also obtained from the hybridization of female TC and male BSB $[2,5,6]$.

In the process of speciation, hybridization and genetic introgression between species are a relatively frequent occurrence, particularly in rapidly radiating biological populations, promoting species formation [1, 7-10]. Numerous studies demonstrated that hybrid fish lineages exhibited unique phenotypes and genotypes [1-6]. The formation of distant hybrid lineages is of great importance in genetic breeding and biological evolution.

In eukaryotes, the genes encoding 5S ribosomal RNA (rRNA) are composed of tandem repeat units, and every repeat unit is formed by a highly variable non-transcribed spacer (NTS) region and a highly conserved coding region of the $5 \mathrm{~S}$ rRNA gene (approximately $120 \mathrm{bp}$ ) [11-13]. Many researchers demonstrated that the NTS sequence could be used as a molecular genetic marker for species identification and phylogenetic analysis [14-17]. Hybridization can affect the organization and sequences of the 5S rRNA genes of the hybrid, including base substitutions and insertion-deletions [18]. Moreover, hybridization can induce the loss of the parental-special 5S ribosomal DNA (rDNA) unit and can even form the novel unit. For example, after analysing the 5S rRNA genes in different ploidy-level hybrids derived from female RCC $\times$ male TC, He et al. [19] found that a paternalspecial unit lost and a novel unit was generated in the hybrid offspring.

In animals, Sox genes have a conserved motif encoding a high-mobility group (HMG) DNA-binding domain of 79 amino acids, regulating the binding of specific DNA sequences [20-24]. More than 100 Sox genes were found in many organisms, including nematodes, fishes, amphibians, reptiles, birds, mammals and hexapods [24-28]. Through Sox-HMG analysis of 42 types of animals, including birds, reptiles, amphibians, natural fishes, artificial hybrid fishes and hexapods, Chen et al. [27] verified that the HMG domain of the Sox gene was specific in various species and was a new and highly conserved molecular marker sequence.

Based on our previous study, we performed intersubfamily hybridization by crossing female Bleeker's yellow tail (Xenocypris davidi Bleeker, YT) and male TC, possessing the same number of chromosomes $(2 n=48)$. YT and TC are both famous and important economic freshwater fish in China. In zootaxy, YT is an omnivore with strong resistance belonging to the Xenocyprininae subfamily [29]. TC, characterized by its topmouth, is a carnivore with high-quality meat but poor resistance belonging to the Cultrinae subfamily [30,31]. In terms of shape, YT is round with a long body, and the TC is linear with a long and low body. In this study, diploid hybrids $(2 \mathrm{nYC})$ were successfully obtained by mating female YT with male TC, and the new $F_{1}$ hybrids with improved characteristics, such as faster growth rate, stronger resistance, and high-quality meat, might have great significance for fish genetic breeding. This study provided guidance for further study of the general laws of distant hybridization.

\section{Results}

\section{Fertilization rates and hatching rates}

The average fertilization rate and hatching rate of all groups were listed in Table 1 . The fertilization rate and hatching rate of the hybrids $\left(\mathrm{YT}(\right.$ ㅇ $\left.) \times \mathrm{TC}\left({ }^{\Uparrow}\right)\right)$ were 85 and $77 \%$, respectively. The results showed that the fertilization rate and hatching rate of the experimental group $\left(\mathrm{YT}(+) \times \mathrm{TC}\left(\mathcal{O}^{\Uparrow}\right)\right)$ was not significantly differently $(P>0.05)$ from those of the control groups $(\mathrm{YT}(+) \times \mathrm{YT}$ $(\AA)$ and TC $($ P $) \times$ TC $(\hat{\jmath}))$. However, only $2 \%$ of the offspring of YT $($ P $) \times \mathrm{TC}($ ( ) survived to adulthood, and only approximately 100 living hybrids were obtained each year.

\section{Phenotypes of the hybrid and its parents}

The phenotypes of YT (Fig. 1a), TC (Fig. 1b) and 2nYC (Fig. 1c) were illustrated in Fig. 1, and these results showed that $2 \mathrm{nYC}$ was characterized by slight topmouth and high dorsum. The values for the six countable traits (lateral line scales, upper and lower lateral line scales, dorsal fin rays, abdominal fin rays, and anal fin rays) in YT, TC, and 2nYC were presented in Table 2. The number of upper lateral line scales in $2 \mathrm{nYC}$ individuals was intermediate (13-14), with values between those for YT (10-12) and TC (16-20), revealing that 2nYC possessed a hybrid-type shape. However, the number of lower lateral line scales in $2 \mathrm{nYC}$ was slightly higher than those in the parents, indicating variability in 2nYC.

The average BL/WL, HL/BL, BH/BL, HH/HL, HH/BH, and $\mathrm{CPH} / \mathrm{CPL}$ ratios were shown in Table 3 . We discovered significant differences $(P<0.01)$ between YT and $2 \mathrm{nYC}$ for all measurable traits, indicating that the appearance of $2 \mathrm{nYC}$ was strikingly different from that of YT. Likewise, there were significantly differences $(P<$ 0.01 ) in the $\mathrm{BL} / \mathrm{WL}, \mathrm{HL} / \mathrm{BL}, \mathrm{HH} / \mathrm{HL}, \mathrm{HH} / \mathrm{BH}$, and $\mathrm{CPH} /$ $\mathrm{CPL}$ ratios between $\mathrm{TC}$ and $2 \mathrm{nYC}$, suggesting that $2 \mathrm{nYC}$ was different from $\mathrm{TC}$ in terms of most phenotypic traits. The ratios of $\mathrm{HH} / \mathrm{HL}$ and $\mathrm{HH} / \mathrm{BH}$ for $2 \mathrm{nYC}$ were numerically intermediate between those for $\mathrm{YT}$ and TC, indicating that $2 \mathrm{nYC}$ exhibited a variable hybrid-type shape for these morphological traits. Peculiarly, the HL/ $\mathrm{BL}$ ratio was significantly higher in $2 \mathrm{nYC}$ than in either

Table 1 Fertilization rate and hatching rate of YT, TC and their hybrid offspring

\begin{tabular}{|c|c|c|}
\hline Groups & Fertilization rate (\%) & Hatching rate (\%) \\
\hline $\mathrm{YT}(\mathrm{q}) \times \mathrm{YT}\left(\mathrm{O}^{\Uparrow}\right)$ & 85.5 & 70 \\
\hline $\mathrm{TC}(\mathrm{q}) \times \mathrm{TC}\left(\mathrm{O}^{\pi}\right)$ & 84 & 69 \\
\hline YT $($ Q $) \times \mathrm{TC}($ đ) & 85 & 77 \\
\hline
\end{tabular}




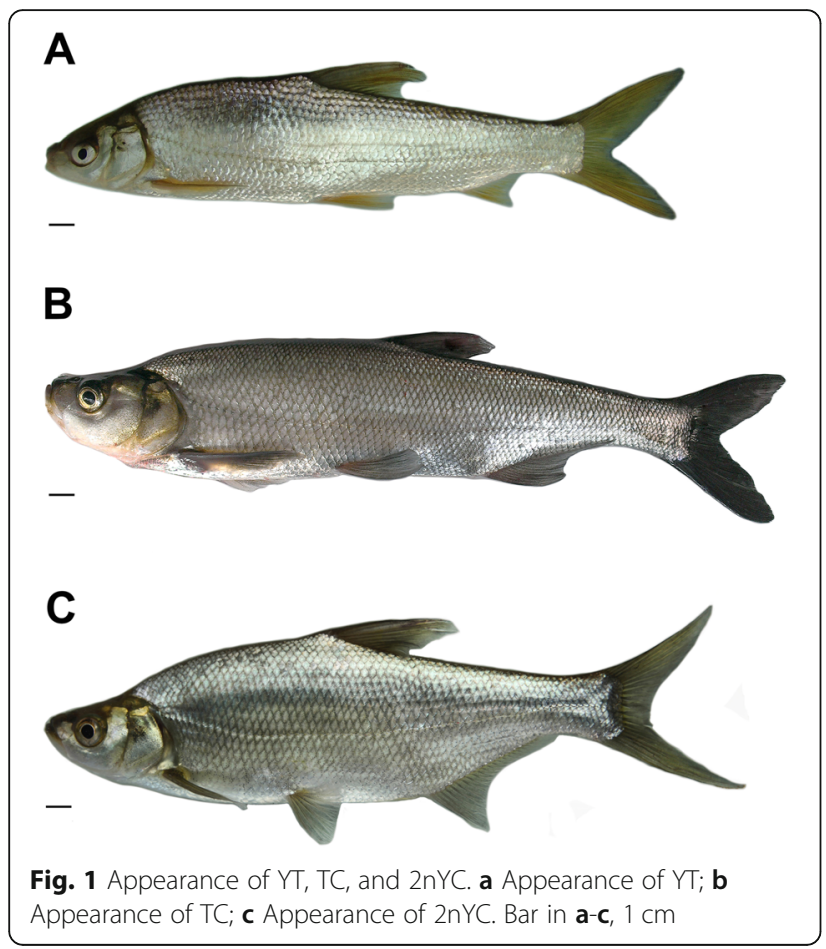

$\mathrm{YT}$ or $\mathrm{TC}$, and the $\mathrm{CPH} / \mathrm{CPL}$ ratio in $2 \mathrm{nYC}$ was lower than that in either YT or TC.

\section{DNA content}

We used the DNA content of the parents (YT and TC) as the control. The comparison of the DNA content of YT, TC, and 2nYC was presented in Table 4. The results showed that the DNA content of $102 \mathrm{nYC}$ from YT $(P) \times \mathrm{TC}(\delta)$ was equal $(P>0.05)$ to the sum of half YT and half $\mathrm{TC}$, suggesting that $2 \mathrm{nYC}$, which might receive half of their chromosomes from YT and half the TC, were diploid, similar to the parent fish.

\section{Chromosome number of the hybrid and its parents}

The chromosome number distribution of $\mathrm{YT}, \mathrm{TC}$, and $2 \mathrm{nYC}$ was shown in Table 3. Of the YT individuals examined, $98 \%$ of the chromosomal metaphase spreads had 48 chromosomes, indicating that they were diploids with 48 chromosomes $(2 n=48)$ (Table 5 , Fig. $2 a)$. Of the TC individuals examined, $93 \%$ of the chromosomal metaphase spreads possessed 48 chromosomes, showing that they were diploids with 48 chromosomes $(2 n=48)$
(Table 5, Fig. 2b). Additionally, 95.5\% of the chromosomal metaphase spreads in $2 \mathrm{nYC}$ possessed 48 chromosomes, indicating that they were also diploids with 48 chromosomes $(2 \mathrm{n}=48)$ (Table 5, Fig. 2c). In addition, according to the classification standards reported by Levan et al. [32], YT, TC, and 2nYC possessed the same karyotype formula of $18 \mathrm{~m}+26 \mathrm{sm}+4 \mathrm{st}$, including a pair of large submetacentric chromosomes (Fig. 2).

\section{Molecular analysis of polymorphisms in 5S rDNA sequences}

The primers (5SP1 and 5SP2R) were used to amplify DNA fragments from $\mathrm{YT}, \mathrm{TC}$, and $2 \mathrm{nYC}$, and the results of agarose gel electrophoresis showed that YT had three bands (approximately 200, 250, and $400 \mathrm{bp}$ ), TC had three bands (approximately 200, 280, and $400 \mathrm{bp}$ ), and 2nYC had three bands (approximately 200, 280, and 400 bp) (Fig. 3). A total of 120 clones (30 from YT, 30 from $\mathrm{TC}$ and 60 from $2 \mathrm{nYC}$ ) were generated to further evaluate the differences in $5 \mathrm{~S}$ rDNA patterns (Table 6). The sequencing results indicated that $\mathrm{YT}$ had three different sizes (188, 221, and $376 \mathrm{bp})$, TC had three different sizes $(188,286$, and $376 \mathrm{bp})$, and $2 \mathrm{nYC}$ had four different sizes (188, 212, 287 and 376 bp) (Table 6). Sequence analysis revealed that $2 \mathrm{nYC}$ had two similarly sized $5 \mathrm{~S}$ rDNA sequences (188 and $212 \mathrm{bp}$ ) that were indistinguishable on the agarose gel, where they appeared as a single band of approximately $200 \mathrm{bp}$.

BLASTn was used for sequence analysis, and all fragments of YT, TC, and $2 \mathrm{nYC}$ were shown to be $5 \mathrm{~S}$ rDNA repeat units that consisted of a highly conserved coding region $(120 \mathrm{bp})$ and highly variable NTS regions of different lengths. In YT, the two monomeric 5S rDNA classes (designated class I: $188 \mathrm{bp}$ and class II: $221 \mathrm{bp}$ ) were characterized by diverse NTS types (designated NTS-I: $68 \mathrm{bp}$ and NTS-II: $101 \mathrm{bp}$ ). In TC, the two monomeric 5S rDNA classes (designated class I: 188 bp and class III: $286 \mathrm{bp}$ ) were characterized by disparate NTS types (designated NTS-I: 68 bp and NTS-III: 166 bp). 2nYC inherited class I (188 bp) and class III (287 bp) from its parents but derived a new $5 \mathrm{~S}$ rDNA class (designated class IV: $212 \mathrm{bp}$ ) with a novel NTS type (designated NTS-IV: 92 bp). However, no maternal-specific 5S rDNA sequence (class II) was found in 2nYC. All $5 \mathrm{~S}$ rDNA sequences were submitted to GenBank, and their accession numbers were listed in Table 7. A comparison of

Table 2 Countable traits of $Y T, T C$, and $2 n Y C$

\begin{tabular}{|c|c|c|c|c|c|c|}
\hline $\begin{array}{l}\text { Fish } \\
\text { type }\end{array}$ & $\begin{array}{l}\text { Number of lateral } \\
\text { line scales }\end{array}$ & $\begin{array}{l}\text { Number of upper lateral } \\
\text { line scales }\end{array}$ & $\begin{array}{l}\text { Number of lower lateral } \\
\text { line scales }\end{array}$ & $\begin{array}{l}\text { Number of dorsal } \\
\text { fin rays }\end{array}$ & $\begin{array}{l}\text { Number of abdominal } \\
\text { fin rays }\end{array}$ & $\begin{array}{l}\text { Number of anal } \\
\text { fin rays }\end{array}$ \\
\hline YT & $60-67$ & $10-12$ & $6-8$ & $|I|+7-9$ & $8-9$ & $\mid I I+11-13$ \\
\hline TC & 80-92 & $16-20$ & $6-7$ & $\| I I+7$ & 9 & $I I I+20-23$ \\
\hline $2 n Y C$ & $64-66$ & $13-14$ & $9-10$ & $\|||+8$ & $9-10$ & $|I|+22-23$ \\
\hline
\end{tabular}


Table 3 Measurable traits of $Y T, T C$, and $2 n Y C$

\begin{tabular}{lllllll}
\hline Fish type & $\mathrm{BL} / \mathrm{LL}^{\mathrm{a}}$ & $\mathrm{HL} / \mathrm{BL} \mathrm{L}^{\mathrm{a}}$ & $\mathrm{BH} / \mathrm{BL}^{\mathrm{a}}$ & $\mathrm{HH} / \mathrm{HL} \mathrm{L}^{\mathrm{a}}$ & $\mathrm{HH} / \mathrm{BH}^{\mathrm{a}}$ & $\mathrm{CPH} / \mathrm{CPL}^{\mathrm{a}}$ \\
\hline YT & $0.82 \pm 0.02$ & $0.20 \pm 0.13$ & $0.27 \pm 0.15$ & $0.79 \pm 0.04$ & $0.57 \pm 0.08$ & $0.65 \pm 0.13$ \\
TC $^{\mathrm{b}}$ & $0.84 \pm 0.02$ & $0.20 \pm 0.22$ & $0.25 \pm 0.13$ & $0.46 \pm 0.29$ & $0.44 \pm 0.26$ & $0.85 \pm 0.11$ \\
2nYC & $0.83 \pm 0.01$ & $0.22 \pm 0.15$ & $0.25 \pm 0.44$ & $0.61 \pm 0.08$ & $0.52 \pm 0.09$ & $0.53 \pm 0.17$ \\
\hline
\end{tabular}

${ }^{a} B L$ body length, $W L$ whole length, $H L$ head length, $B H$ body height, $H H$ head height, $C P H$ caudal peduncle height, $C P L$ caudal peduncle length

${ }^{b} 20$ samples were counted for each kind of fish

class I from YT and 2nYC showed a base substitution, and two base substitutions were found between $\mathrm{TC}$ and 2nYC (Fig. 4). A comparison of class III from TC and $2 \mathrm{nYC}$ revealed a base substitution (C-G) in the NTS regions and a deletion-insertion of an adenine residue (Fig. 4). A comparison of class II from YT and class IV from $2 \mathrm{nYC}$ showed two base substitutions (C-T and T$\mathrm{G}$ ) in the coding regions, even in the A box, but not in the internal element (IE) or C box. Moreover, there were significant differences in the non-coding regions, mainly showing an insertion-deletion and obvious nucleotide variations (Fig. 4). All the internal control regions that function as gene promoters (A box, IE and C box) were detected. Within all the NTS sequences of YT, TC, and $2 \mathrm{nYC}$, the TATA box control element was detected and had been modified to TAAA. The poly-T tract required for transcription termination was also detected (Fig. 4).

\section{DNA fragments of Sox genes}

Primers (HMG (+) and HMG (-)) were used to amplify DNA fragments from $\mathrm{YT}, \mathrm{TC}$, and $2 \mathrm{nYC}$, and the results of agarose gel electrophoresis showed that there were two bands (approximately 200 and $700 \mathrm{bp}$ ) in YT, $\mathrm{TC}$, and 2nYC (Fig. 5). Twenty clones were selected for sequencing and analysis of each band to further assess the differences in Sox patterns, and there were three different DNA fragments in YT $(215,215$, and $710 \mathrm{bp})$, three in TC $(215,215$, and $726 \mathrm{bp})$, and four in $2 \mathrm{nYC}$ $(215,215,710$, and $726 \mathrm{bp})$.

Table 4 Mean DNA content of $\mathrm{YT}, \mathrm{TC}$, and 2nYC

\begin{tabular}{|c|c|c|c|c|c|}
\hline \multirow{2}{*}{$\begin{array}{l}\text { Fish } \\
\text { type }\end{array}$} & \multirow{2}{*}{$\begin{array}{l}\text { Mean } \\
\text { DNA } \\
\text { content }^{\mathrm{a}}\end{array}$} & \multirow[t]{2}{*}{ Deviation } & \multirow{2}{*}{$\begin{array}{l}\text { Variation } \\
\text { coefficient } \\
(\%)\end{array}$} & \multicolumn{2}{|l|}{ Ratio } \\
\hline & & & & Observed ratio & Expected ratio \\
\hline$\overline{\mathrm{YT} 1}$ & 66.71 & 0.072 & 3.37 & $2 \mathrm{nYC1} /(0.5 \mathrm{YT} 1+0.5 \mathrm{TC} 1)=1.04^{\mathrm{b}}$ & 1 \\
\hline YT2 & 65.29 & -1.348 & 5.12 & & \\
\hline YT3 & 67.64 & 1.002 & 4.19 & & \\
\hline YT4 & 65.43 & -1.208 & 4.80 & & \\
\hline YT5 & 68.12 & 1.482 & 3.12 & & \\
\hline TC1 & 65.07 & 0.926 & 6.76 & & \\
\hline TC2 & 64.10 & -0.044 & 4.56 & & \\
\hline TC3 & 62.73 & -1.414 & 5.65 & & \\
\hline TC4 & 64.53 & 0.386 & 4.15 & & \\
\hline TC5 & 64.29 & 0.146 & 3.84 & & \\
\hline $2 n Y C 1$ & 68.40 & -0.517 & 6.21 & & \\
\hline $2 n Y C 2$ & 70.18 & 1.263 & 4.32 & & \\
\hline $2 n Y C 3$ & 71.42 & 2.503 & 7.53 & & \\
\hline $2 n Y C 4$ & 67.19 & -1.727 & 4.64 & & \\
\hline $2 n Y C 5$ & 69.98 & 1.063 & 2.13 & & \\
\hline $2 n Y C 6$ & 69.18 & 0.263 & 3.56 & & \\
\hline $2 n Y C 7$ & 66.23 & -2.687 & 4.11 & & \\
\hline $2 n Y C 8$ & 67.87 & -1.047 & 5.98 & & \\
\hline $2 n Y C 9$ & 70.59 & 1.673 & 7.87 & & \\
\hline 2nYC10 & 68.13 & -0.787 & 6.95 & & \\
\hline
\end{tabular}

${ }^{\mathrm{a}}$ The intensity of fluorescence (unit, channel)

${ }^{\mathrm{b}}$ The observed ratio was not significantly different $(P>0.05)$ from the expected ratio 
Table 5 Distribution of chromosome number in $\mathrm{YT}, \mathrm{TC}$, and 2nYC

\begin{tabular}{lllll}
\hline Fish & $\begin{array}{l}\text { Number } \\
\text { type }\end{array}$ & $\begin{array}{l}\text { Number of } \\
\text { metaphase }\end{array}$ & \multicolumn{2}{l}{ Distribution of chromosome number } \\
\cline { 5 - 5 } & spreads & $<48$ & 48 \\
\hline YT & 5 & 100 & 2 & 98 \\
TC & 5 & 100 & 7 & 93 \\
2nYC & 10 & 200 & 9 & 191 \\
\hline
\end{tabular}

BLASTn was employed for sequence analysis. The resulting data were summarized in Table 8 and indicated that there were two different DNA fragments with lengths of $215 \mathrm{bp}$ in $2 \mathrm{nYC}$ and its parents, one belonging to the Sox1 gene and the other belonging to the Sox11 gene. A 710 bp DNA fragment existed in YT and $2 \mathrm{nYC}$ and belonged to the Sox 9 gene, whereas a 726 bp DNA fragment in TC and 2nYC also belonged to the Sox9 gene. We compared all fragments belonging to Sox genes in YT, TC, and $2 n Y C$. In the Sox 1 sequences, which consisted of a 215 bp DNA fragment, two base substitutions were found between $\mathrm{YT}$ and $\mathrm{TC}$; the sequence in $2 \mathrm{nYC}$ was exactly the same as that in the paternal TC and had two base substitutions compared with that in the maternal YT (Fig. 6a). In the Sox11 sequences, which consisted of a 215 bp DNA fragment, two base substitutions were found between $\mathrm{YT}$ and $\mathrm{TC}$; similarly, the sequence in $2 \mathrm{nYC}$ had two base substitutions compared with that in the parental $\mathrm{TC}$ and four base substitutions compared with that in the maternal YT (Fig. 6b). In addition, the $710 \mathrm{bp}$ gene fragment in $2 \mathrm{nYC}$, which was derived from the maternal YT, exhibited $100 \%$ similarity with the $710 \mathrm{bp}$ gene fragment in YT. The 726 bp gene fragment in $2 n Y C$, which was derived from the paternal TC, exhibited $100 \%$ similarity with the 710 bp gene fragment in TC (Fig. 6c).

\section{Chromosomal loci of 5S rDNA}

The 188 bp 5S rDNA unit was used as a hybridization probe with the mitotic metaphase chromosomes of $\mathrm{YT}, \mathrm{TC}$, and $2 \mathrm{nYC}$. In the present investigation using $\mathrm{FISH}$, four fluorescent signals of $5 \mathrm{~S}$ rDNA were found in most of the metaphase spreads of YT, TC and their hybrid offspring. Comparison of the chromosomal location indicated that two signals were positioned on a pair of the largest submetacentric chromosomes, and the other two were on a pair

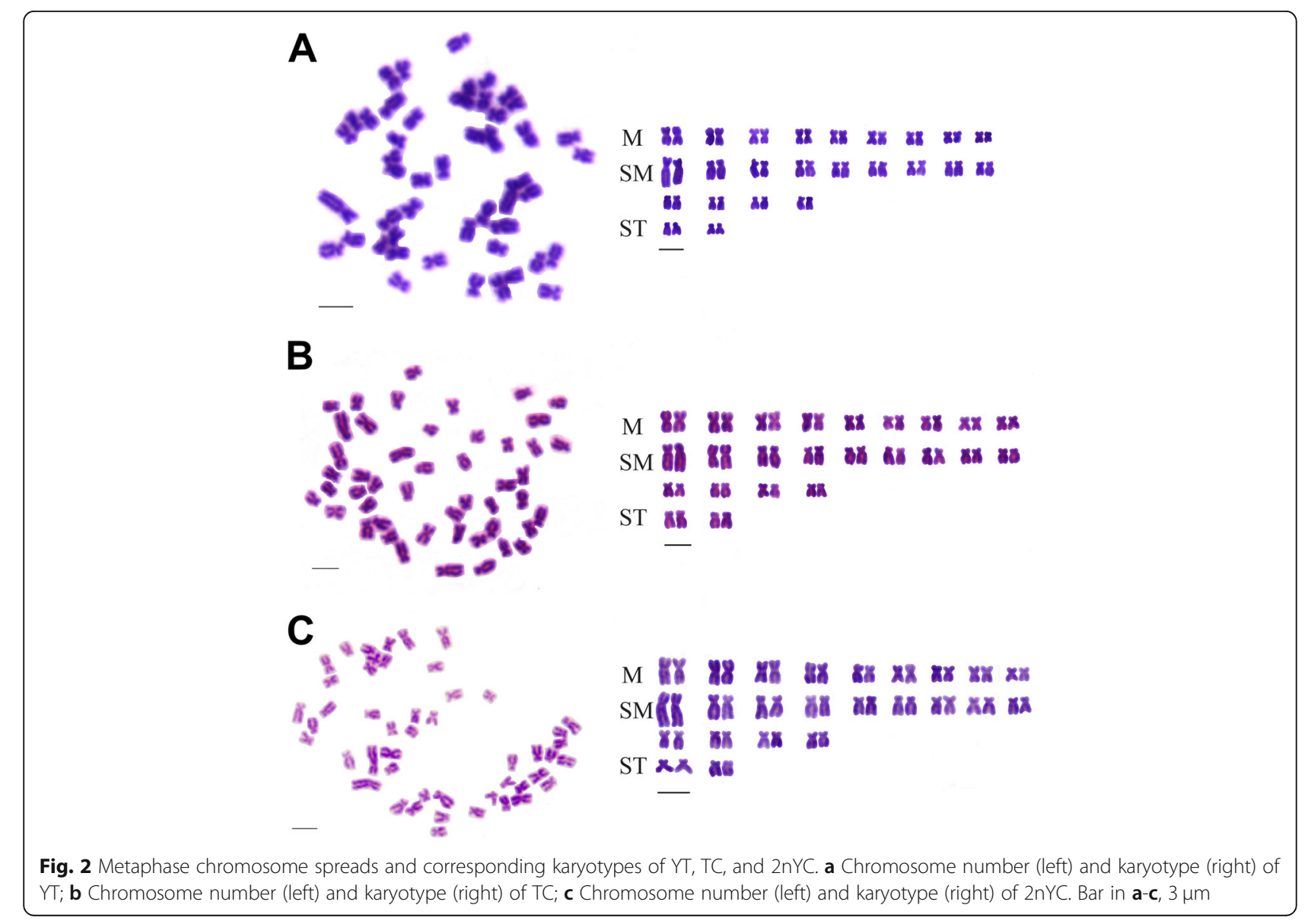




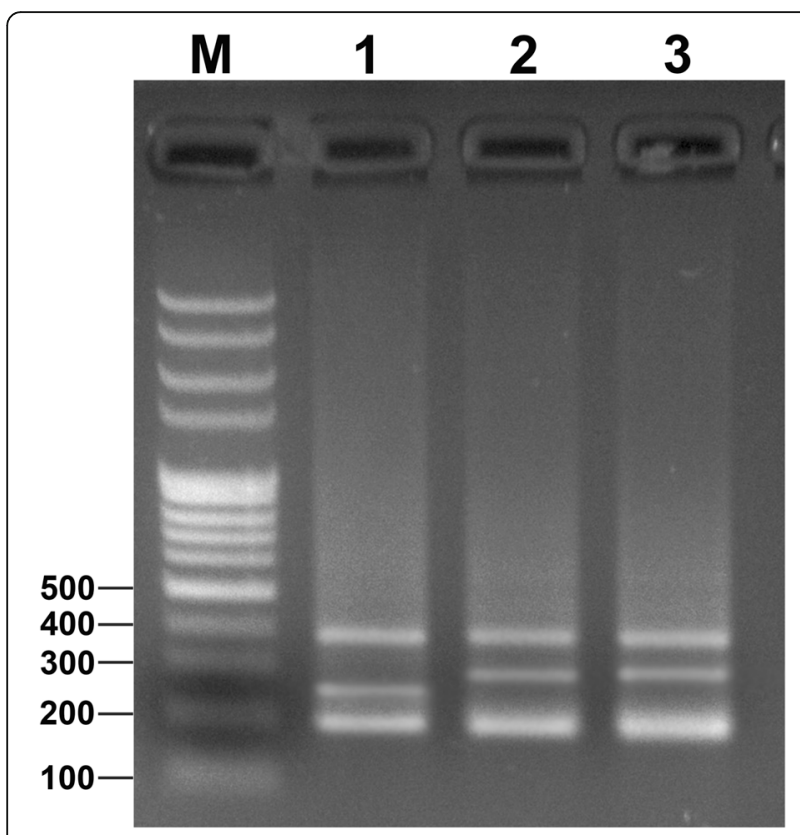

Fig. 3 PCR-generated 5S rDNA products obtained from YT, TC, and 2 nYC. M, DNA ladder markers (100 bp increments); lane 1, three bands (approximately 200, 250, and $400 \mathrm{bp}$ ) from YT; lane 2, three bands (approximately 200, 280, and $400 \mathrm{bp}$ ) from TC; lane 3, three bands (approximately 200, 280, and $400 \mathrm{bp}$ ) from $2 \mathrm{nYC}$

of subtelocentric chromosomes (Fig. 7). All the 5S rDNA loci were near the centromere. These results indicated that the 188 bp 5S rDNA unit could be used as an effective marker in future investigations of the ploidy of a hybrid resulting from YT and TC.

\section{Analysis of hybrid gonadal development}

Figure 8 presented the ovarian microstructure of 2year-old $2 \mathrm{nYC}$. At the time of analysis, the ovaries had developed normally and had entered phase IV. Meanwhile, a large number of oocytes at phase II were observed, and a small number of oogonia were found. However, all the tested testes of the male hybrids could not produce mature sperm.
Table 7 GenBank accessions of the $5 \mathrm{~S}$ rDNA sequences from YT, TC, and 2nYC

\begin{tabular}{llll}
\hline $\begin{array}{l}\text { DNA } \\
\text { fragments } \\
\text { (bp) }\end{array}$ & \multicolumn{3}{l}{ GenBank accession number of the sequences } \\
\cline { 2 - 4 } & YT & TC & 2nYC \\
\hline 188 & MN158655 & MN158657 & MN158659 \\
212,221 & MN158656 & Absent & MN158660 \\
286,287 & Absent & MN158658 & MN158661 \\
\hline
\end{tabular}

\section{Discussion}

Distant hybridization, i.e., the translation of the haploid genome of one species into another species, may lead to genotypic and phenotypic changes in the offspring. Moreover, distant hybridization is proven to be a useful way to create new fish species in fish genetic breeding, fish reproduction, and aquaculture. Due to nuclear-cytoplasmic incompatibility and other reasons, it is difficult to obtain fish offspring via distant hybridization between orders, families, and subfamilies. The obtained hybrid offspring were usually considered to be the result of gynogenesis. However, studies on the fertilization cytology of Ctenopharyngodon idellus (grass carp, GC) $($ ( $) \times$ Megalobrama terminalis ( $\left.{ }^{\Uparrow}\right)$ [33] and CC $\left(\right.$ ( ) $\times$ GC $\left({ }^{\lambda}\right)$ [34] showed that there were also normal fertilization events that occurred between these distantly related species. Previous studies indicated that diploid hybrid offspring were sparse in the $F_{1}$ generation of some distant crosses $[1,6,33-37]$. For example, no diploid hybrid offspring were obtained among $\mathrm{F}_{1}$ hybrids of RCC $(+) \times \mathrm{BSB}$

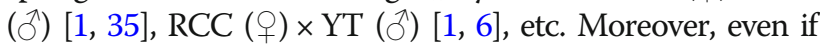
diploid hybrid offspring were produced among $F_{1}$ hybrids of female RCC and male TC, their fertility was not good enough $[6,19]$. In the present study, we obtained diploid $F_{1}$ hybrid offspring by mating of female YT with male TC, which belonged to different subfamilies but with the same chromosome number. The ploidy level of $2 \mathrm{nYC}$ was verified by measuring the DNA content, counting the chromosomal number (Fig. 2c), observing the karyotype (Fig. 2c), and FISH analysis (Fig. 7c). All of the results above confirmed that $2 \mathrm{nYC}$ was diploid with 48 chromosomes. Histological observation showed that $2 \mathrm{nYC}$ underwent normal ovarian development (Fig. 8) and produced mature eggs. Similarly,

Table 6 Results of 5 S sequencing

\begin{tabular}{|c|c|c|c|c|c|}
\hline \multirow[t]{2}{*}{ Species } & \multirow{2}{*}{$\begin{array}{l}\text { Total } \\
\text { number of } \\
\text { sequenced } \\
\text { clones }\end{array}$} & \multicolumn{4}{|l|}{ PCR fragments } \\
\hline & & $\sim 200 \mathrm{bp}$ & $\sim 250 \mathrm{bp}$ & $\sim 280 \mathrm{bp}$ & $\sim 400 \mathrm{bp}$ \\
\hline$\overline{\mathrm{YT}}$ & 30 & $\begin{array}{l}\text { Ten sequenced } \\
\text { clones of } 188 \mathrm{bp}\end{array}$ & $\begin{array}{l}\text { Ten sequenced } \\
\text { clones of } 221 \mathrm{bp}\end{array}$ & Absent & $\begin{array}{l}\text { Ten sequenced } \\
\text { clones of } 376 \mathrm{bp}\end{array}$ \\
\hline $\mathrm{TC}$ & 30 & $\begin{array}{l}\text { Ten sequenced } \\
\text { clones of } 188 \mathrm{bp}\end{array}$ & Absent & $\begin{array}{l}\text { Ten sequenced } \\
\text { clones of } 286 \text { bp }\end{array}$ & $\begin{array}{l}\text { Ten sequenced } \\
\text { clones of } 376 \text { bp }\end{array}$ \\
\hline $2 n Y C$ & 60 & $\begin{array}{l}\text { Nine sequenced } \\
\text { clones of } 188 \mathrm{bp} ; \\
\text { eleven sequenced } \\
\text { clones of } 212 \mathrm{bp}\end{array}$ & Absent & $\begin{array}{l}\text { Twenty sequenced } \\
\text { clones of } 287 \mathrm{bp}\end{array}$ & $\begin{array}{l}\text { Twenty sequenced } \\
\text { clones of } 376 \mathrm{bp}\end{array}$ \\
\hline
\end{tabular}


TC-class I 2nYC-class I

YT-class I 2nYC-class IV YT-class II TC-class III 2nYC-class III

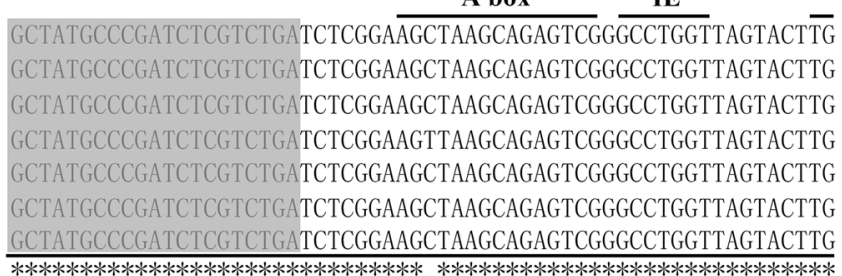

60

TC-class I
2nYC-class I
YT-class I
2nYC-class IV
YT-class II
TC-class III
2nYC-class III

\section{C box}

GATGGGAGACCGCCTGGGAATACCAGGTGCTGTAAGCTTTATGTTTTTTCT-GATGGGAGACCGCCTGGGAATACCAGGTGCTGTAAGCTTTATGTTTTTTCT---GATGGGAGACCGCCTGGGAATACCAGGTGCTGTAAGCTTTATGTTTTTTCT--------GATGGGAGACCGCCTGGGAATACCAGGTGCGGTAAGCTTTATGTTTTATTTTGTTCAAAGATGGGAGACCGCCTGGGAATACCAGGTGCTGTAAGCTTTATGTTTATTTCAAAAGAAAG GATGGGAGACCGCCTGGGAATACCAGGTGCTGTAAGCTTTATGTTTTTTCAAAAAAAAAA GATGGGAGACCGCCTGGGAATACCAGGTGCTGTAAGCTTTATGTTTTTTCAAAAAAAAAA ********************************* $* * * * * * * * * * * * * * * *$

TC-class I 2nYC-class I YT-class I 2nYC-class IV YT-class II TC-class III 2nYC-class III

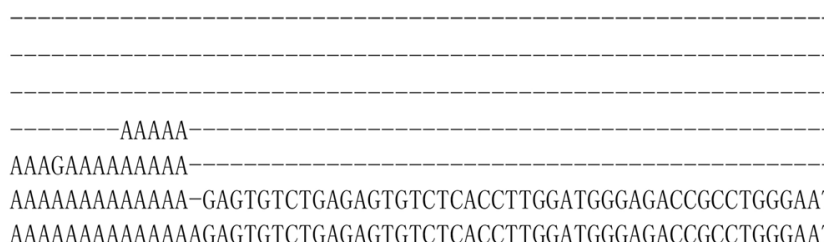

TC-class I 2nYC-class I YT-class I 2nYC-class IV YT-class II TC-class III 2nYC-class III

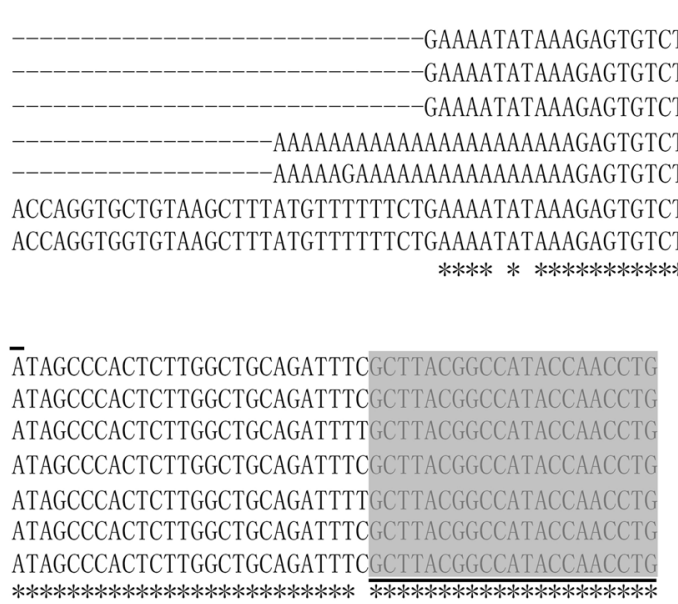

TATA box

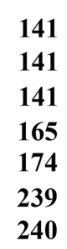

TC-class I
2nYC-class I
YT-class I
2nYC-class IV
YT-class II
TC-class III
2nYC-class III

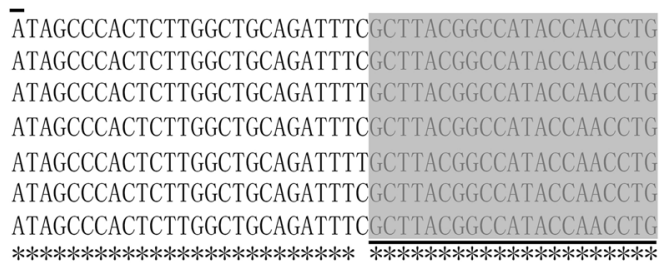

188

188

188

212

221

286

287

Fig. 4 Comparison of class I, class II, class III, and class IV from YT, TC, and 2nYC. The coding region of the 5S rDNA is underlined, and the primers used to amplify $5 \mathrm{~S}$ rDNA are shaded. Asterisks indicate consistent nucleotides

previous studies indicated that fertile diploid hybrid offspring were obtained by mating of female BSB and TC, and their parents possessed the same chromosome number [38]. Therefore, we speculated that the formation of fertile diploid hybrid offspring was related to the chromosome number of the parents. Parents with the same chromosome number is a prerequisite for the generation of diploid hybrid offspring. In addition, we could obtain triploid hybrids in the $F_{1}$ generation of hybridization when the number of maternal chromosomes was equal to that of paternal chromosomes, as described in previous studies [31, 38, 39]. However, there was no triploid generated by the hybridization of female YT and male TC in this study. We speculated that the absence of triploid formation might be attributed to the reason that the second meiosis could be normally carried out and the second polar body could be normally emitted.

In the process of distant hybridization, the $F_{1}$ hybrid offspring tended to integrate favourable parental traits and exhibit heterosis [40, 41]. In terms of countable traits, the $2 \mathrm{nYC}$ hybrids presented an intermediate number of upper lateral line scales compared to YT and TC (Table 2 ). In terms of measurable traits, the $2 \mathrm{nYC}$ hybrids 


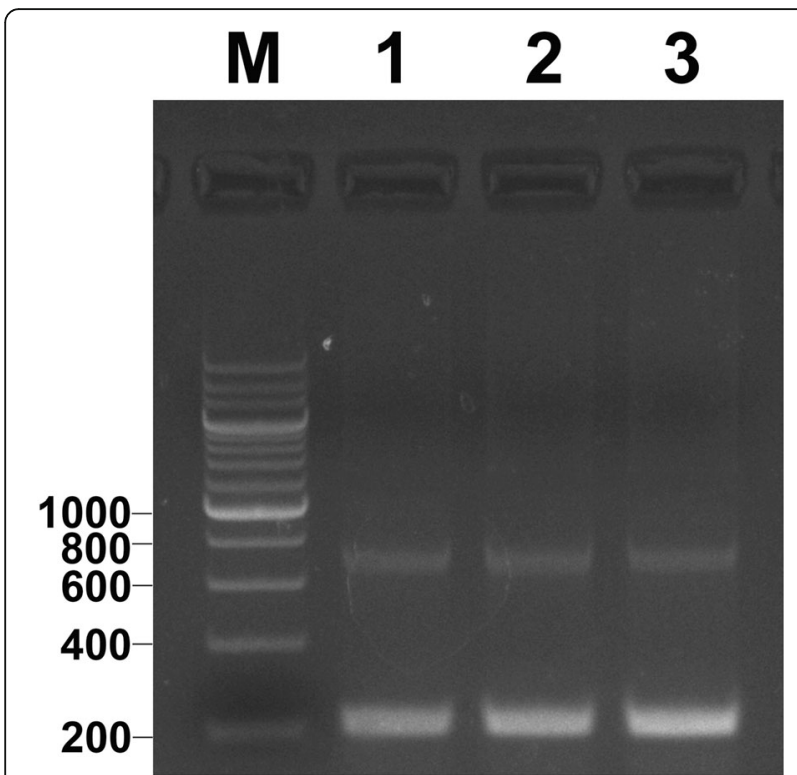

Fig. 5 PCR-generated Sox products obtained from $Y T, T C$, and $2 n Y C$. M, DNA ladder markers (200 bp increments); lane 1, two bands (approximately 200 and $700 \mathrm{bp}$ ) from $\mathrm{YT}$; lane 2, two bands (approximately 200 and $700 \mathrm{bp}$ ) from TC; lane 3, two bands (approximately 200 and $700 \mathrm{bp}$ ) from $2 \mathrm{nYC}$

exhibited a lower $\mathrm{CPH} / \mathrm{CPL}$ ratio compared to their parents (Table 3). These traits could act as morphological markers to distinguish the hybrids from their parents. In short, the hybrids showed hybrid characteristics and hybrid heterosis. Moreover, our results provided support for the hybrid origin of the offspring of YT $(+9) \times \mathrm{TC}\left({ }^{\lambda}\right)$, rather than the outcome of gynogenesis or androgenesis. Moreover, $2 \mathrm{nYC}$ exhibited the high fertilization rate and the hatching rate but the low adult survival rate.

Compared with the 5S rDNA results of He et al. [19] and $\mathrm{Wu}$ et al. [42], our results showed that different TC individuals exhibited genetic diversity. Other studies also confirmed that TC exhibited some genetic variability [43]. Previous studies showed that hybridization could lead to variation in the structure and sequence of $5 \mathrm{~S}$ rDNA, including base substitutions and deletioninsertions in the NTS sequence, parental genomespecific loss, and formation of new 5S rDNA classes [19]. In this study, two types of 5S rDNA classes were detected in $\mathrm{YT}$ and $\mathrm{TC}$, which favoured the hypothesis that the presence of two types of $5 \mathrm{~S}$ rDNA classes was a

Table 8 Sox genotypes of $2 n Y C$ and its parents

\begin{tabular}{llll}
\hline DNA fragments & YT & TC & 2nYC \\
\hline $215 \mathrm{bp}$ & Sox1 & Sox1 & Sox1 \\
$215 \mathrm{bp}$ & Sox11 & Sox11 & Sox11 \\
$710 \mathrm{bp}$ & Sox9 & Absent & Sox9 \\
$726 \mathrm{bp}$ & Absent & Sox9 & Sox9 \\
\hline
\end{tabular}

general trend in 5S rRNA gene organization in the fish genome [44]. However, $2 \mathrm{nYC}$ had three types of $5 \mathrm{~S}$ rDNA classes, partially inheriting 5S rDNA classes from their parents. 2nYC inherited the $188 \mathrm{bp}$ and $287 \mathrm{bp}$ fragments from its parents but also obtained a novel $5 \mathrm{~S}$ rDNA unit (212 bp), which revealed heredity and variability in 2nYC at the molecular level and that these variations were related to hybridization. To reduce incompatible parental genetic material, rapid genetic recombination was needed in 2 nYC hybrids, which led to the presence of a novel 5S rDNA and the absence of parental-specific 5S rDNA. Hybridization can lead to genomic changes, including changes in gene expression, chromosome structure and genome size [45]. In the present study, we observed two nucleotide mutations in the coding region of the hybrid offspring, even in the A box (Fig. 4). We also detected nucleotide polymorphisms, including base insertion-deletions and substitutions in the NTS sequences of the hybrid offspring (Fig. 4). Numerous studies indicated that the NTS sequence could be used as a molecular genetic marker for species identification and phylogenetic analysis [14-18]. Comparative analysis of the NTS sequence demonstrated that 2nYC hybrids had three types of NTS sequences (NTS-I, NTS-III, and NTSIV), among which NTS-IV showed an insertiondeletion and obvious nucleotide variations compared to NTS-II. We speculated that this phenomenon might be the result of the allele being inherited from the female parent and the production of recombinant mutations. Meanwhile, NTS-I of 2nYC was highly homologous to those of YT and TC, and NTS-III of 2nYC was also highly homologous to that of TC. These results indicated that distant hybridization could induce base insertions, deletions and substitutions in the NTS sequence and that these variations in the NTS sequence were always species-specific. Thus, we determined that the NTS sequence could act as an effective molecular marker to distinguish hybrid offspring and their parents. Similarly, 2nYC inherited Sox9 (710 bp) from YT and Sox9 (726 bp) from TC, which suggested the heredity in $2 \mathrm{nYC}$. Thus, the Sox gene fragments could also serve as feasible molecular genetic markers to distinguish hybrids and their parents.

FISH is a valid method for determining the chromosomal location of 5S rDNA [46]. This technology, combined with cytogenetic and molecular genetic methodologies, was proven to be very useful for establishing cytogenetic maps and performing genomic studies $[47,48]$. In fish, 5S rDNA can be found in more than one single chromosome pair [49]. A total of 41 species of representative cichlids were mapped to 5S rRNA genes to obtain an improved understanding of the genomic organization of rRNA genes and chromosomal evolution [50]. In the genus Leporinus, 


\begin{tabular}{|c|c|}
\hline $\begin{array}{l}\text { TC-Sox1 } \\
\text { 2nYC-Sox1 } \\
\text { YT-Sox1 }\end{array}$ & 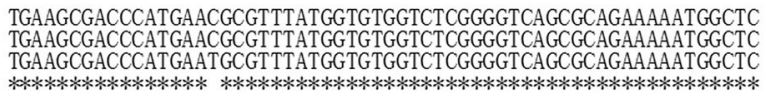 \\
\hline $\begin{array}{l}\text { TC-Sox1 } \\
\text { 2nYC-Sox1 } \\
\text { YT-Sox1 }\end{array}$ & 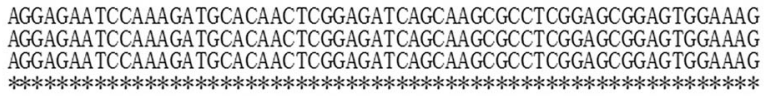 \\
\hline $\begin{array}{l}\text { TC-Sox1 } \\
\text { 2nC-Sox1 } \\
\text { YT-SOX1 }\end{array}$ & 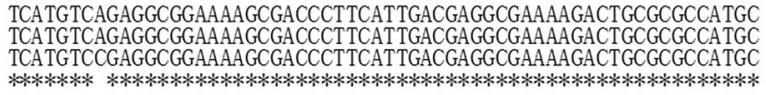 \\
\hline $\begin{array}{l}\text { TC-Sox1 } \\
\text { 2nYC-Sox1 } \\
\text { YT-Sox1 }\end{array}$ & 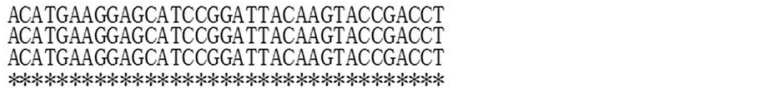 \\
\hline $\begin{array}{l}\text { YT-Sox11 } \\
\text { TC-Sox11 } \\
\text { 2nYC-Sox } 11\end{array}$ & 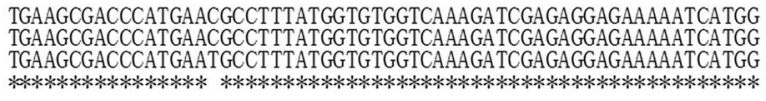 \\
\hline $\begin{array}{l}\text { YT-Sox } 11 \\
\text { TC-Sox11 } \\
2 \text { nYC-SOX11 }\end{array}$ & 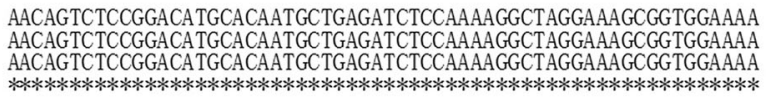 \\
\hline $\begin{array}{l}\text { YT-Sox11 } \\
\text { TC-Sox11 } \\
\text { 2nYC-SOX11 }\end{array}$ & 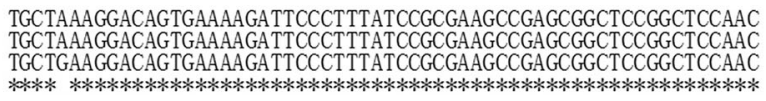 \\
\hline $\begin{array}{l}\text { YT-Sox } 11 \\
\text { TC-SOX11 } \\
\text { 2nYC-SOX11 }\end{array}$ & $\begin{array}{l}\text { ACATGGCTGACTACCCCGATTATAAGTACCGACCT } \\
\text { ACATGGCTGACTACCCCGACTACAAGTACCGACCT } \\
\text { ACATGGCTGACTACCCCGACTACAAGTACCGACCT }\end{array}$ \\
\hline
\end{tabular}

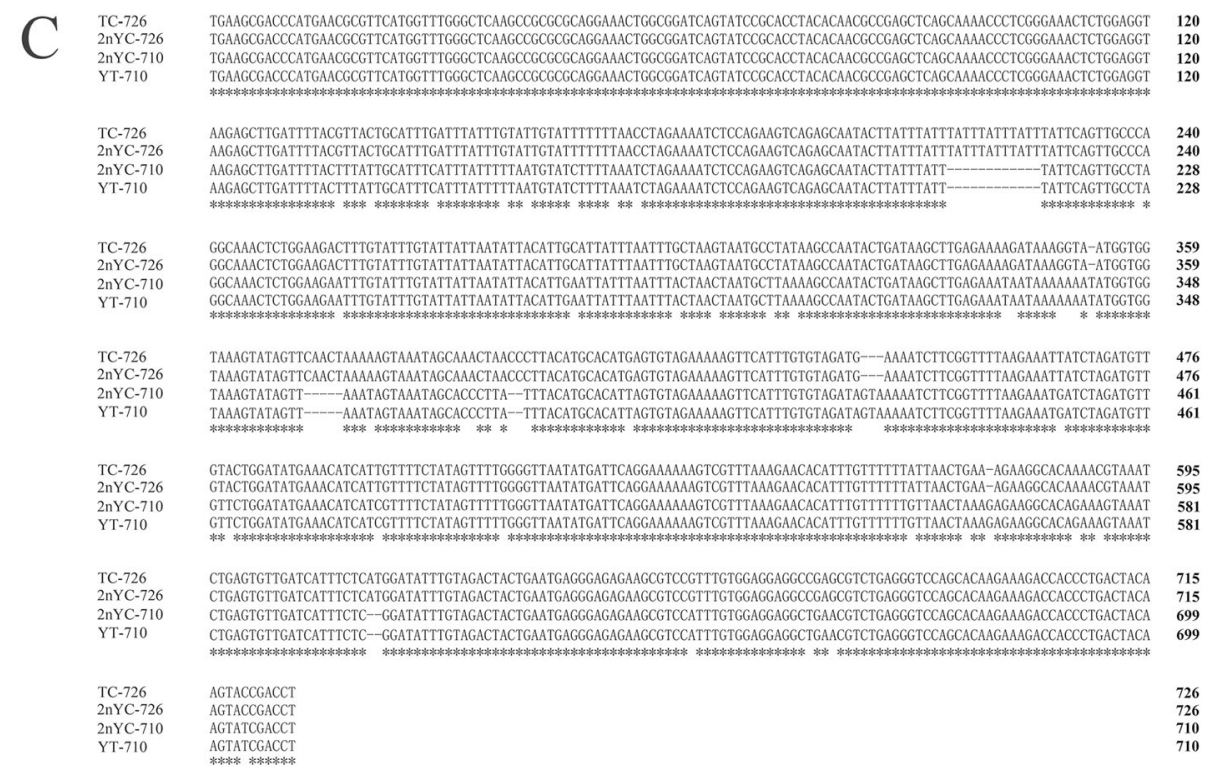

Fig. 6 Alignment of Sox sequences. a Alignment of Sox1 sequences from YT, TC, and 2nYC; b Alignment of Sox11 sequences from YT, TC, and 2nYC. c Alignment of Sox9 sequences from YT, TC, and 2nYC. Asterisks indicate consistent nucleotides

different 5S rDNA arrays characterized two possible $5 S$ rRNA gene subfamilies that evolved independently in the genome [51]. In this study, the chromosomal localization of the $5 \mathrm{~S}$ rRNA gene unit revealed that there were two signals in a haploid chromosome set, one in the largest submetacentric chromosome and the other in the subtelocentric chromosome. Therefore, the 188 bp $5 \mathrm{~S}$ rDNA probe could be used to detect the ploidy level of the hybrids, which were derived from $\mathrm{YT}$ or $\mathrm{TC}$.

\section{Conclusions}

This research offered solid genetic evidence to support the successful formation of diploid hybrids, and $2 \mathrm{nYC}$ exhibited heredity and variability, as determined by analysis of morphological traits, ploidy, 5S rDNA, Sox, 

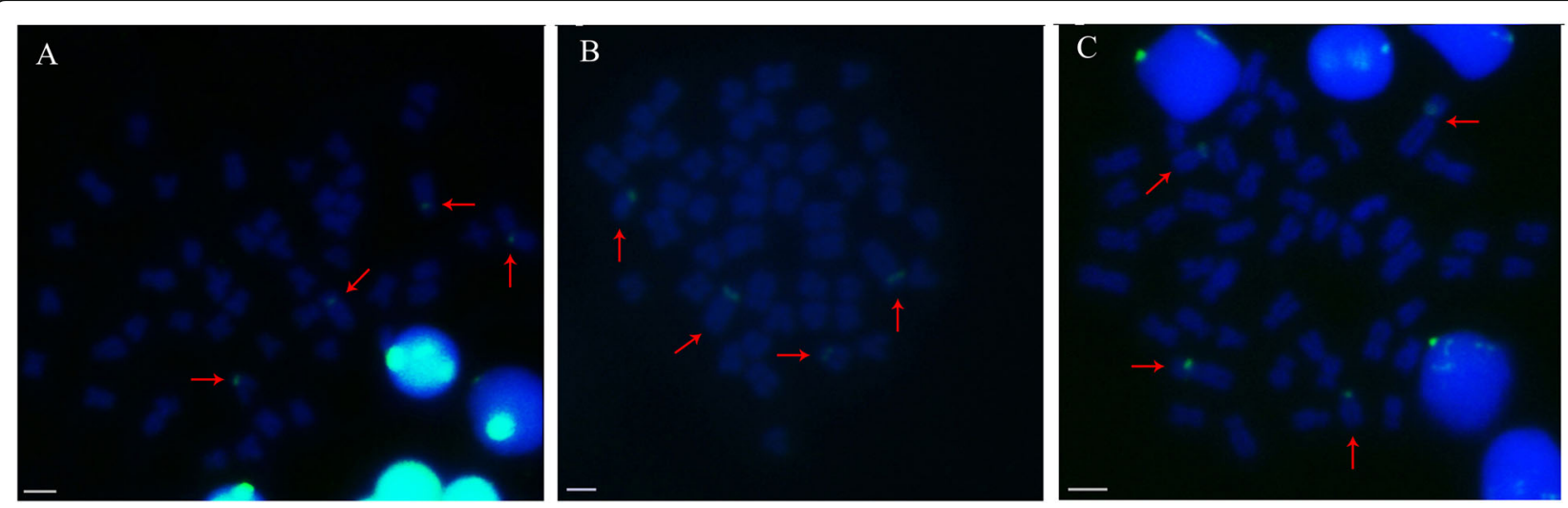

Fig. 7 FISH hybridization signals in YT, TC, and 2nYC with 188 bp 5S rDNA as a probe. Fluorescein isothiocyanate (FITC)-conjugated avidin was used to detect signals, and 4',6-diamidino-2-phenylindole (DAPI) was used to stain all the metaphase chromosomes. The red arrows manifest the hybridizing signals. The four hybridizing signals in $\mathrm{YT} \mathbf{a}, \mathrm{TC} \mathbf{b}$, and $2 \mathrm{nYC} \mathbf{c}$ are shown. Bars in $\mathbf{a}-\mathbf{c}, 3 \mu \mathrm{m}$

and fertility. The production of fertile female hybrid fish not only provided the possibility of creating a new type of fish but also expanded the range of genetic material available for breeding. In the future, we will generate a hybrid lineage by back-crossing the female diploid hybrids with their parents. In addition, these results further revealed the influence of hybridization on the organization and genetic variation in 5S rDNA multigene families.

\section{Methods}

\section{Animals and crosses}

Sexually mature YT and TC were obtained from the Engineering Research Center of Polyploid Fish Breeding and Reproduction of the State Education Ministry at Hunan Normal University. All experiments performed were approved by the Animal Care Committee of Hunan Normal University. Approval was acquired for the Administration of Affairs Concerning Animal Experimentation guidelines from the Science and Technology Bureau of China. To minimize suffering, $100 \mathrm{mg} / \mathrm{L} \mathrm{MS-222} \mathrm{(Sigma-Aldrich,} \mathrm{St} \mathrm{Louis,}$ MO, USA) was used to anaesthetize fish before dissection.

During the reproductive seasons since 2010, crosses between female YT and male TC were performed. The mature eggs were fertilized with the mature sperm, and the embryos were incubated in freshwater at $22-26^{\circ} \mathrm{C} .2 \mathrm{nYC}\left(\mathrm{F}_{1}\right)$ was obtained in this crossgroup. Meanwhile, self-mating of both YT and TC was conducted as a control. Concrete implementation was performed based on the patented "A method of distant crossing between Xenocypris davidi and Erythroculter ilishaeformis" (patent no. ZL 20121 0449551.7) [52]. Two thousand embryos were selected at random from each group to examine the fertilization rate (number of embryos at the gastrula stage $/ 2000 \times 100 \%$ ) and hatching rate (number of hatched fry $/ 2000 \times 100 \%$ ). The data from six parallel experiments for each group were analysed by analysis of variance (ANOVA) using SPSS Statistics 19.0 (IBM, USA). The hatched fry was transferred to a pond for further cultivation.

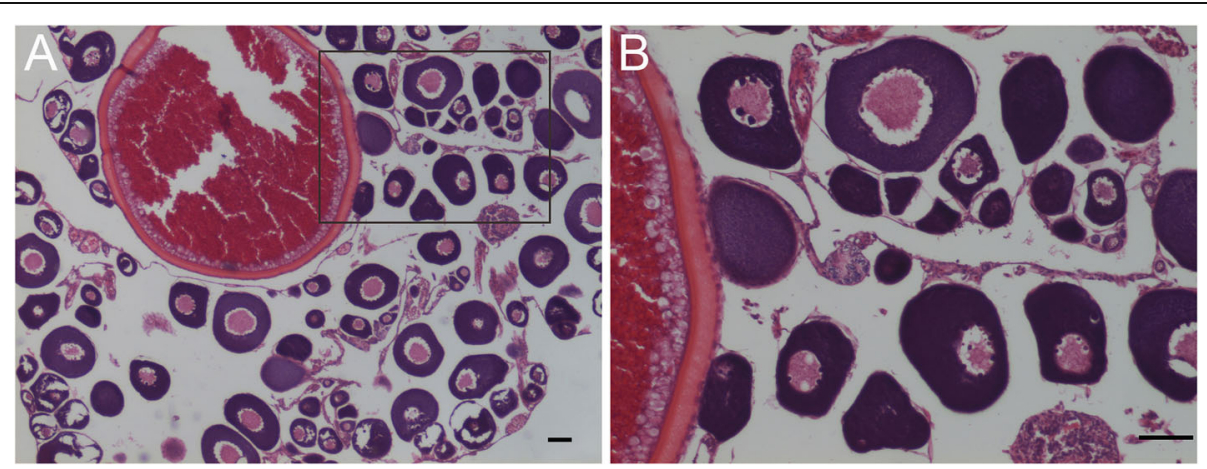

Fig. 8 Ovary microstructure of $2 n Y C$. a Histological section of the ovary of $2 n Y C$. The part in the black frame is enlarged in $\mathbf{b}$. Bars in $\mathbf{a}$ and b, $50 \mu \mathrm{m}$ 


\section{Measurement of morphological traits}

At 2 years of age, $20 \mathrm{YT}, 20 \mathrm{TC}$, and 20 2nYC individuals were taken at random for morphological examination. The examination standards followed a kind of schematic diagram of the studied seven measurable traits [53]. Six countable traits of each fish (lateral line scales, upper and lower lateral line scales, dorsal fin rays, abdominal fin rays, and anal fin rays) were recorded. Seven measurable traits (whole length, body length and height, head length and height, and caudal peduncle length and height) were also recorded (accurate to $0.1 \mathrm{~cm}$ ). The average ratios of body length to whole length (BL/WL), head length to body length (HL/BL), body height to body length $(\mathrm{BH} / \mathrm{BL})$, head height to head length $(\mathrm{HH} /$ $\mathrm{HL})$, head height to body height $(\mathrm{HH} / \mathrm{BH})$, and caudal peduncle height to caudal peduncle length $(\mathrm{CPH} / \mathrm{CPL})$ were calculated. SPSS Statistics 19.0 (IBM, USA) was used to conduct ANOVA and pairwise comparisons of the data between every two kinds of fish in YT, TC, and 2nYC.

\section{Ploidy determination of the hybrid}

Peripheral blood was collected from the caudal veins of $5 \mathrm{YT}, 5 \mathrm{TC}$ and $102 \mathrm{nYC}$ individuals with the age of more than six months from each group using a syringe containing sodium heparin and then treated according to the method described by Liu et al. [35]. Blood samples were subjected to nuclear extraction and 4',6-diamidino-2-phenylindole (DAPI) DNA staining with CyStain DNA 1 Step (Partec, Germany) and then filtered with a nylon filter (Partec, Germany). A flow cytometer (Cell Counter Analyzer, Partec, Germany) was used to measure the mean comparative DNA content, and RCC was used as the control. The mean DNA content of each sample was measured under the same conditions. Eventually, a $X^{2}$ test using SPSS Statistics 19.0 software (IBM, USA) with Yate's correction was used to examine the deviation in the ratios of the mean DNA content of $2 \mathrm{nYC}$ to the sum of that from YT and TC from expected ratio values.

\section{Preparation of chromosome spreads}

Chromosome preparation was performed with cultured peripheral blood cells of the hybrids and their parents as described by Huang et al. [54] with minor modifications. For each fish sample, 100, 100, and 200 metaphase spreads (20 spreads per sample) from YT, TC, and 2nYC were examined, respectively. A total of $0.2 \mathrm{ml}$ of blood was collected using a syringe and cultured in nutrient solution (83\% RPMI 1640, 15\% foetal bovine serum, $0.002 \%$ heparin sodium, phytohemagglutinin, $0.5 \%$ penicillin and $10,000 \mathrm{U} /$ $\mathrm{ml}$ streptomycin) at $27^{\circ} \mathrm{C}$ with $5 \% \mathrm{CO}_{2}$ for $72 \mathrm{~h}$, adding colchicine (final concentration, $0.6 \mu \mathrm{g} / \mathrm{ml}$ ) for $3.5 \mathrm{~h}$ before the end of cultivation. Cells were harvested by centrifugation, and the erythrocytes were ruptured by hypotonic treatment with $0.075 \mathrm{M} \mathrm{KCl}$ at $37^{\circ} \mathrm{C}$ for $30-40 \mathrm{~min}$ and then fixed in 3:1 methanol-acetic acid with three changes. Cells were dropped onto a cold and wet slide, airdried and stained with $4 \%$ Giemsa solution for $30 \mathrm{~min}$. All the images were obtained using an oil lens at a magnification of 330x. High-quality metaphase spreads were photographed for karyotype analysis. The lengths of the entire chromosomes, as well as the long and short arms, were measured. Chromosomes were classified according to Levan et al. [32].

\section{Cloning of the 5S rRNA genes and sox genes}

Total genomic DNA of YT, TC, and 2nYC was isolated from the whole blood collected from the fish caudal vein based on the method described by Sambrook et al. [55]. A pair of primers (5SP1， 5'-GCTATGCCCGATCTCGTCTGA-3'; 5SP2R, 5'-CAGGTTGGTATGGCCGTAAGC-3') was designed as described by Qin et al. [18] and synthesized by Sangon (Shanghai, China), and the 5S rRNA genes were directly amplified from the genomic DNA according to a previous study [19]. Similarly, a set of degenerate primers (HMG (+), 5'-TGAAGCGACCCATGAA(C/T) G-3'; HMG (-), 5' AGGTCG(A/G)TACTT(A/G)TA(A/G)T-3') was designed by Chen et al. [26] and synthesized by Sangon (Shanghai, China), and polymerase chain reaction (PCR) amplification of the HMG-box DNA fragments of the Sox genes was performed based on the method described by Chen et al. [26]. The PCR amplification products were separated on a $1.5 \%$ agarose gel using TBE buffer, purified using a gel extraction kit (UNIQ-10 Column DNA Gel Extraction Kit, Sangon), and cloned into the pMD18-T vector (TaKaRa, Dalian, China). The recombinant plasmids with the DNA fragments were transferred into competent Escherichia coli DH5 $\alpha$, and positive clones were sequenced by Sangon. For the purpose of analysing sequence homology and variation among the amplified products from YT, TC, and 2nYC, Bioedit [56] and Clustal W2 software [57] were used to align sequences.

\section{Fluorescence in situ hybridization}

Fluorescence in situ hybridization (FISH) probes for the $5 \mathrm{~S}$ rRNA gene were constructed for YT. The PCR and temperature adjustments were executed as previously described by Qin et al. [46] with minor modifications. The temperature profile was as follows: initial denaturation step at $94{ }^{\circ} \mathrm{C}$ for $5 \mathrm{~min}$, followed by 30 cycles of $94^{\circ} \mathrm{C}$ for $30 \mathrm{~s}$, $60^{\circ} \mathrm{C}$ for $30 \mathrm{~s}$, and $72^{\circ} \mathrm{C}$ for $1 \mathrm{~min}$, with a final extension step at $72^{\circ} \mathrm{C}$ for $10 \mathrm{~min}$. The purified PCR products were labelled by Dig-11-dUTP (using the Nick Translation Kit, Roche, Germany) to produce FISH probes, and FISH was carried out as described by $\mathrm{He}$ et al. [19]. After treatment with $30 \mu \mathrm{g} / \mathrm{ml}$ RNase A in $2 \times \mathrm{SSC}$ for $30 \mathrm{~min}$ at $37^{\circ} \mathrm{C}$, the slides with chromosome metaphase spreads were denatured in $70 \%$ deionized formamide $/ 2 \times \mathrm{SSC}$ for $2 \mathrm{~min}$ at $70^{\circ} \mathrm{C}$, 
dehydrated in 70, 90 and 100\% ethanol for 5 min each, and then air-dried. The hybridization mixture (approximately $100 \mathrm{ng}$ of labelled probes, $50 \%$ formamide, $10 \mathrm{mg}$ dextran sulfate $/ \mathrm{ml}$ and $2 \times \mathrm{SSC}$ ) was denatured in boiling water for $10 \mathrm{~min}$ and applied to air-dried slides carrying denatured metaphase chromosomes under a $22 \times 22 \mathrm{~mm}$ coverslip. The slides were then placed in a moist chamber and incubated overnight at $37^{\circ} \mathrm{C}$. After overnight incubation, the coverslips were removed, and the slides were rinsed at $43{ }^{\circ} \mathrm{C}$ in $2 \times$ SSC with $50 \%$ formamide twice for $15 \mathrm{~min}$ each, $2 \times$ SSC for $5 \mathrm{~min}$, and $1 \times$ SSC for $5 \mathrm{~min}$ and then air-dried. Spectral signals were obtained by administering $8 \mu \mathrm{l}$ of $5 \mu \mathrm{g} / \mathrm{ml}$ Fluorescein isothiocyanate (FITC)-conjugated antidigoxigenin antibody derived from sheep (Roche, Germany) and finally incubating in a humidity chamber at $37^{\circ} \mathrm{C}$. After a series of washes with TNT (containing $0.1 \mathrm{M}$ Tris- $\mathrm{HCl}, 0.15 \mathrm{M} \mathrm{NaCl}, 0.05 \%$ Tween 20 ) at $43^{\circ} \mathrm{C}$, the slides were covered in antifade solution containing $2 \mu \mathrm{g} / \mathrm{ml}$ DAPI for $5 \mathrm{~min}$. For each type of fish, 60 complete metaphase spreads with 48 chromosomes (20 $\mathrm{YT}, 20 \mathrm{TC}$, and $20 \mathrm{2nYC}$ ) were analysed under a Leica inverted CW4000 microscope and a Leica LCS SP2 confocal imaging system (Leica, Germany). Captured images were coloured and overlapped in Adobe Photoshop CS6.

\section{Histological observation of the hybrid gonads}

At 2 years of age, $52 \mathrm{nYC}$ individuals were selected at random for histological observation of the gonadal structure via paraffin sectioning. The ovaries were fixed in Bouin's solution, dehydrated in an increasing ethanol gradient, cleared in xylene, embedded in paraffin, sectioned using a Leica RM2016 microtome (Germany) and stained with haematoxylin and eosin. Ovary sections were examined and photographed using an Olympus microscope CX41 (Japan), and ovarian development in each sample was classified based on the previous standards for cyprinid fish [58].

\section{Abbreviations \\ 2nYC: Diploid hybrids; 4nAT: Allotetraploid hybrids; ANOVA: Analysis of variance; $B H / B L$ : Body height to body length; BL/WL: Body length to whole length; BSB: Blunt snout bream; CC: Common carp; CPH/CPL: Caudal peduncle height to caudal peduncle length; DAPI: 4',6-diamidino-2- phenylindole; FISH: Fluorescence in situ hybridization; GC: Grass carp; HH/ BH: Head height to body height; $\mathrm{HH} / \mathrm{HL}$ : Head height to head length; $\mathrm{HL} /$ BL: Head length to body length; HMG: High-mobility group; IE: Internal element; NTS: Non-transcribed spacer; PCR: Polymerase chain reaction; RCC: Red crucian carp; rDNA: Ribosomal DNA; rRNA: Ribosomal RNA; TC: Topmouth culter; YT: Bleeker's yellow tail}

\section{Acknowledgements}

Not applicable.

\section{Authors' contributions}

This study was conceived and designed by SJL. SNL performed the statistical analyses and wrote the manuscript. The experimental work was performed by SNL, MT, LHX, JX, LJY, and TZ. The experimental materials were collected by KKL and RRZ. The manuscript was modified by SJL, MT, and CZ. All authors read and approved the final manuscript.

\section{Funding}

This work was supported by the National Natural Science Foundation of China (Grant No. 31430088, 31872551, 91631305), the earmarked fund for China Agriculture Research System (Grant No. CARS-45), Hunan Provincial Natural Science and Technology Major Project (Grant No. 2017NK1031), the Cooperative Innovation Center of Engineering and New Products for Developmental Biology of Hunan Province (Grant No. 20134486). Experimental animals, reagents, and consumables are derived from these funds, which provide strong support for the study and collection, analysis, and interpretation of data and in writing the manuscript.

\section{Availability of data and materials}

All the datasets used and/or analysed throughout the present study are available from the corresponding author on reasonable request.

\section{Ethics approval and consent to participate}

All experiments performed were approved by the Animal Care Committee of Hunan Normal University. Approval was acquired for the Administration of Affairs Concerning Animal Experimentation guidelines from the Science and Technology Bureau of China. All fishes were cultured in natural ponds, MS-222 anaesthesia was used to perform all dissections to minimize suffering.

\section{Consent for publication}

Not applicable.

\section{Competing interests}

The authors declare that they have no competing interests.

\section{Author details}

${ }^{1}$ State Key Laboratory of Developmental Biology of Freshwater Fish, Hunan Normal University, Changsha 410081, Hunan, China. ${ }^{2}$ College of Life Sciences, Hunan Normal University, Changsha 410081, Hunan, China.

Received: 13 February 2019 Accepted: 26 September 2019 Published online: 23 October 2019

\section{References}

1. Liu SJ. Distant hybridization leads to different ploidy fishes. Sci China Life Sci. 2010;53:416-25.

2. Wang S, Tang CC, Tao M, Qin QB, Zhang C, Luo KK, Zhao RR, Wang J, Ren L, Xiao J, et al. Establishment and application of distant hybridization technology in fish. Sci China Life Sci. 2019;62:22-45.

3. Liu SJ, Cao YC, He XX, Li JZ, Liu Y. The formation of tetraploid hybrids of common carp with red crucian carp and evolutionary significance of tetraploidization in vertebrate. Eng Sci. 2001;3:33-41.

4. Oin QB, Wang YD, Wang J, Dai J, Xiao J, Hu FZ, Luo KK, Tao M, Zhang C, Liu $Y$, et al. The Autotetraploid fish derived from hybridization of Carassius auratus red var. (female) $\times$ Megalobrama amblycephala (male). Biol Reprod. 2014;91:93.

5. Chen J, Luo M, Li SN, Tao M, Ye XL, Duan W, Zhang C, Qin QB, Xiao J, Liu SJ. A comparative study of distant hybridization in plants and animals. Sci China Life Sci. 2018;61:285-309.

6. Liu SJ. Fish distant hybridization. Beijing: Science Press; 2014.

7. Comai L. The advantages and disadvantages of being polyploidy. Nat Rev Genet. 2005:6:836-46.

8. Liu SJ, Liu Y, Zhou GJ, Zhang XJ, Luo C, Feng H, He XX, Zhu GH, Yang $H$. The formation of tetraploid stocks of red crucian carp $\times$ common carp hybrids as an effect of interspecific hybridization. Aquaculture. 2001;192:171-86.

9. Seehausen O. Hybridization and adaptive radiation. Trends Ecol Evol. 2004; 19:198-207.

10. Zhu X. Discussion about the fertilization process of animal hybridization Chin Sci Bull. 1961;7:1-7.

11. Bogenhagen DF, Brown DD. Nucleotide sequences in Xenopus 5S DNA required for transcription termination. Cell. 1981;24:261-70.

12. Long EO, Dawid IB. Repeated genes in eukaryotes. Annu Rev Biochem. 1980;49:727-64.

13. Pasolini P, Costagliola D, Rocco L, Tinti F. Molecular organization of $5 S$ rDNAs in Rajidae (Chondrichthyes): structural features and evolution of 
piscine 5S rRNA genes and nontranscribed intergenic spacers. J Mol Evol. 2006;62:564-74.

14. Campo D, Machado-Schiaffino G, Horreo JL, Garcia-Vazquez E. Molecular organization and evolution of 55 rDNA in the genus Merluccius and their phylogenetic implications. J Mol Evol. 2009;68:208-16.

15. Pendas AM, Moran P, Martinez JL, Garcia-Vazquez E. Applications of $5 S$ rDNA in Atlantic salmon, brown trout, and in Atlantic salmon brown trout hybrid identification. Mol Ecol. 1995;4:275-6.

16. Suzuki H, Moriwaki K, Sakurai S. Sequences and evolutionary analysis of mouse 5S rDNAs. Mol Biol Evol. 1994;11:704-10.

17. Sajdak SL, Reed KM, Phillips RB. Intraindividual and interspecies variation in the 5 S rDNA of coregonid fish. J Mol Evol. 1998;46:680-8.

18. Qin QB, He WG, Liu SJ, Wang J, Xiao J, Liu Y. Analysis of 5 S rDNA organization and variation in polyploid hybrids from crosses of different fish subfamilies. J Exp Zool B Mol Dev Evol. 2010;314B:403-11.

19. He WG, Qin QB, Liu SJ, Li TL, Wang J, Xiao J, Xie LH, Zhang C, Liu Y. Organization and variation analysis of 55 rDNA in different ploidy-level hybrids of red crucian carp $\times$ topmouth culter. PLoS One. 2012;7: e38976.

20. Lenhoff HM. Activation of the feeding reflex in Hydra littoralis: I. role played by reduced glutathione, and quantitative assay of the feeding reflex. J Gen Physiol. 1961;45:331-44.

21. Gubbay J, Collignon J, Koopman P, Capel B, Economou A. A gene mapping to the sexdetermining region of the mouse $Y$ chromosome is a member of a novel family of embryonically expressed genes. Nature. 1990;346:245-50.

22. Sinclair AH, Berta P, Palmer MS, Hawkins JR, Griffiths BL, Smith MJ, Foster JW Frischauf AM, Lovell-Badge R, Goodfellow PN. A gene from the human sexdetermining region encodes a protein with homology to a conserved DNAbinding motif. Nature. 1990;346:240-4.

23. Foster JW, Graves J. An SRY-related sequence on the marsupial $X$ chromosome: implications for the evolution of the mammalian testisdetermining gene. Proc Natl Acad Sci U S A. 1994;91:1927-31.

24. Pevny LH, Lovell-Badge R. Sox genes find their feet. Curr Opin Genet Dev. 1997;7:338-44.

25. Wegner M. From head to toes: the multiple facets of sox proteins. Nucleic Acids Res. 1999;27:1409-20

26. Jiang LX, Li JW, He Y, Li ML, Fang W, Li GQ, Xu YX. Research advances in Sox gene family. Biotechnol Bull. 2008;6:44-8.

27. Chen L, Li W, Liu SJ, Tao M, Long Y, Duan W, Zhang C, Xiao J, Qin QB, Luo $\mathrm{KK}$, et al. Novel genetic markers derived from the DNA fragments of sox genes. Mol Cell Probes. 2009;23:157-65.

28. Waranabe M, Kawasaki K, Kawasaki M, Portaveetus T, Oommen S, Blackburn J, Nagai T, Kitamura A, Nishikawa A, Kodama Y, et al. Spatio-temporal expression of sox genes in murine palatogenesis. Gene Expression Patterns. 2016;21:111-8.

29. Basilewsky S. Ichthyographia Chinae borealis. Nouv Mém Soc Imp Natur Moscou. 1855;10:215-63.

30. Nichols JT. The freshwater fishes of China. Nat Hist Central Asia Am Mus Nat Hist. 1943;9:322.

31. Cui JX, Ren XH, Yu QX. Nuclear DNA content variation in fishes. Cytologia. 1991;56:425-9.

32. Levan A, Fredga K, Sandberg AA. Nomenclature for centromeric position on chromosomes. Hereditas. 1964;52:201-20.

33. Liu SY. Cytological study on fertilization of Ctenopharyngodon idellus $(\$) \times$ Megalobrama terminalis (ふ̋'). J Fish China. 1987;11:225-32.

34. Liu GA, Wu WX, Lin LA, Xu DY, Zheng YG. A cytology study on the cross fertilization of res common carp with grass carp. J Fish China. 1987;11:17-21.

35. Liu SJ, Qin QB, Xiao J, Lu WT, Shen JM, Li W, Liu JF, Duan W, Zhang C, Tao $M$, et al. The formation of the polyploid hybrids from different subfamily fish crossings and its evolutionary significance. Genetics. 2007;176:1023-34.

36. Yang $H$, Xia DQ, Liu L, Wu TT. Studies on hereditary relationship between Oreochromis aurea $(\underset{+}{(}) \times$ Siniperca chuatsi $\left({ }^{(3)}\right)$. J Fish China. 2004;28:594-8.

37. Hu FZ, Wu C, Zhou YF, Cao L, Xiao J, Wang S, Wu YH, Ren L, Liu QF, Li WH, et al. Production of androgenetic, triploid and tetraploid hybrids from the interspecific hybridization of female Japanese crucian carp and male blunt snout bream. Aquaculture. 2018;491:50-8.

38. Xiao J, Kang XW, Xie LH, Qin QB, He ZL, Hu FZ, Zhang C, Zhao RR, Wang J, Luo KK, et al. The fertility of the hybrid lineage derived from female Megalobrama amblycephala $\times$ male Culter alburnus. Anim Reprod Sci. 2014;151:61-70.
39. He WG, Xie LH, Li TL, Liu SJ, Xiao J, Hu J, Wang J, Qin QB, Liu Y. The formation of diploid and triploid hybrids of female grass carp $\times$ male blunt snout bream and their 5S rDNA analysis. BMC Genet. 2013;14:110.

40. Groszmann M, Gonzalez-Bayon R, Lyons RL, Greaves IK, Kazan K, Peacock WJ, Dennis ES. Hormone-regulated defense and stress response networks contribute to heterosis in Arabidopsis F1 hybrids. Proc Natl Acad Sci U S A. 2015;112:E6397-406.

41. Li DJ, Zeng RZ, Li Y, Zhao MM, Chao JQ, Li Y, Wang K, Zhu LH, Tian WM, Liang CZ. Gene expression analysis and SNP/InDel discovery to investigate yield heterosis of two rubber tree F1 hybrids. Sci Rep. 2016;6:24984.

42. Wu C, Huang X, Hu FZ, Ouyang YX, Zhao L, Wang S, Li WH, Fan JJ, Zhang C, Ren $L$, et al. Production of diploid gynogenetic grass carp and triploid hybrids derived from the distant hybridization of female grass carp and male topmouth culter. Aquaculture. 2019;504:462-70.

43. Qi PZ, Qin JH, Xie CX. Determination of genetic diversity of wild and cultured topmouth culter (Culter alburnus) inhabiting China using mitochondrial DNA and microsatellites. Biochem Syst Ecol. 2015;61:232-9.

44. Martins C, Galetti PM. Two 5 S rDNA arrays in neotropical fish species: is it a general rule for fishes? Genetica. 2001;111:439-46.

45. Baack EJ, Rieseberg LH. A genomic view of introgression and hybrid speciation. Curr Opin Genet Dev. 2007;17:513-8.

46. Qin QB, Wang J, Wang YD, Liu Y, Liu SJ. Organization and variation analysis of $5 \mathrm{~S}$ rDNA in gynogenetic offspring of Carassius auratus red var. () $\times$ Megalobrama amblycephala (đ). BMC Genet. 2015;16:26.

47. Rebordinos L, Cross I, Merlo A. High evolutionary dynamism in 5S rDNA of fish: state of the art. Cytogenet Genome Res. 2013;141:103-13.

48. Pérez-García C, Guerra-Varela J, Morán P, Pasantes JJ. Chromosomal mapping of rRNA genes, core histone genes and telomeric sequences in Brachidontes puniceus and Brachidontes rodriguezi (Bivalvia, Mytilidae). BMC Genet. 2010;11:109-17.

49. Martins C, Wasko AP. Organization and evolution of 5 S ribosomal DNA in the fish genome. In: Williams CR, editor. Focus on Genome Research. Hauppauge: Nova Science Publishers; 2004. p. 335-63.

50. Nakajima RT, Cabral-De-Mello DC, Valente GT, Venere PC, Martins C. Evolutionary dynamics of rRNA gene clusters in cichlid fish. BMC Evol Biol. 2012:12:198

51. Martins C, Galetti PM Jr. Organization of $5 S$ rDNA in species of the fish Leporinus: two different genomic locations are characterized by distinct nontranscribed spacers. Genome. 2001;44:903-10.

52. Liu SJ, Xiao J, Tao M, Zhang C, Luo KK, Liu Y, Xie LH. A method of distant crossing between Xenocypris davidi and Erythroculter ilishaeformis. State Intellectual Property Office of the People's Republic of China. ZL 20121 0449551.72014

53. Zou SP, Fang YL, Zhou RQ. Measurement of Characters. Inspection of Germplasm for Cultured Fishes, Part 3. Ministry of Agriculture of the People's Republic of China. GB/T 18654.3-2008 2008.

54. Huang W, Liu QZ, Xie JF, Wang WM, Xiao J, Li SS, Zhang HF, Zhang Y, Liu SJ, Lin HR. Characterization of triploid hybrid groupers from interspecies hybridization (Epinephelus coioides $q \times$ Epinephelus lanceolatus $\delta$ ). Aquaculture Research. 2014;47:1-10.

55. Sambrook J, Fritsch EF, Maniatis T. Molecular cloning. Vol. 2 Cold Spring Harbor Laboratory Press New York; 1989.

56. Hall TA. BioEdit: a user-friendly biological sequence alignment editor and analysis program for windows 95/98/NT. Nucleic Acids Symp Ser. 1999:41:95-8

57. Larkin MA, Blackshields G, Brown N, Chenna R, McGettigan PA, McWilliam H, Valentin F, Wallace IM, Wilm A, Lopez R. Clustal W and Clustal X version 2.0. Bioinformatics. 2007;23:2947-8.

58. Liu Y. Germ Cells of Fish. Propagation Physiology of Main Cultivated Fish in China. Beijing: Agricultural Publishing House; 1993. p. 22-30.

\section{Publisher's Note}

Springer Nature remains neutral with regard to jurisdictional claims in published maps and institutional affiliations. 